\title{
Svaga argument gentemot Drontens dom - ett svar till Knut Sundell
}

\section{ANDERS BERGMARK \& TOMMY LUNDSTRÖM}

Knut Sundell skjuter i sitt svar på vår artikel in sig på två frågor, dels skillnaderna mellan (1) generella och specifika faktorer och dels (2) frågan om skadliga insatser. I övrigt kommenterar han (3) vår "konfrontativa" debattstil och utdelar en del berömmande ord avseende sin egen gärning. Vi tar punkterna en och en.

1. När de gäller förhållandet mellan generella och specifika faktorer tillskriver Sundell oss åsikten att "ALLA insatser /är/ lika effektiva". Det har vi emellertid aldrig påstått. Vad vi sagt är att när väletablerade, teoretiskt trovärdiga och professionellt godtagna (bona fide) psykoterapiformer ställs mot varandra i experimentella studier så är skillnaderna i utfall antingen försumbara eller helt frånvarande. Det är detta som är Drontens dom, och ingenting annat. Det betyder naturligtvis inte att vi tror att vare sig kristallterapi eller fysiska övergrepp mot barn och ungdomar har positiva effekter. I övrigt hänvisar vi till vår ursprungliga artikel.

2. Skadliga effekter är ett Sundellskt favorittema. Han återkommer ofta till rebirthing och holding, interventioner som naturligt- vis kan skada eftersom de, i de versioner som Sundell fokuserar, inkluderar direkta fysiska övergrepp mot barn. Rebirthing och holding är interventioner som knappast är särskilt vanliga i socialt arbete, tvärtom de förekommer så vitt vi vet knappast alls. Vi har därför då och då förvånat oss över att Socialstyrelsen och Sundell inte väljer att diskutera mer näraliggande exempel som SiS isolering och avskiljning av ungdomar, de fysiska övergreppen mot förståndshandikappade som för några år sedan genomfördes av personal i Uppsala utbildade i beteendeförändrande metoder (Hallerfors 2008, Söder \& Finn 2009), eller den hårdhänta regim som (kanske) kan förekomma på HVB-hem som tillämpar så kallad teckenekonomi.

Den viktiga diskussionen om skadliga insatser fördunklas ofta genom att olika former av skada och hur den kan mätas blandas samman. I falled Scared Straight (se vår artikel) handlar skadan om att den beroende variabeln (ungdomarnas brottslighet) påverkas negativt av insatsen som sådan. Fynd av det slaget är emellertid mycket ovanliga. Om vi skall tro Mullen, Shuluk och Soydan (se detta nummer av Socialvetenskaplig tidskrift) är det i stället så att två 
tredjedelar av det sociala arbetets insatser gynnar klienterna. I socialt arbete uppkommer (och uppmärksammas) skador oftast på annat sätt än vad som gäller för Scared Straight. Det handlar till exempel om olika former av hårdhänta uppfostringsprogram, som kanske kan upplevas positiva eller till och med ge en genomsnittligt god effekt på den beroende variabeln, men där man kan befara att alltför många individer upplever sig kränkta och där dessa kränkningar är tillräckligt skäl för att sätta stopp för interventionerna (här har Socialstyrelsen ännu inte bidragit med systematiskt kunskapsunderlag eller metodanvisningar). I detta sammanhang kan det vara på sin plats att påminna sig SBU:s varningar för föräldrastödsprogram vars bieffekter kan vara att barns autonomi kränks (SBU 2010). Kanske är emellertid skadorna i socialt arbete vanligast när det gäller insatser där det knappast är aktuellt att förbjuda åtgärderna som sådana. Det tydligaste exemplet är dygnsvården där vi vet att det $\mathrm{i}$ vissa fall förekommer psykiska och fysiska övergrepp mot barn och unga, men där övergreppen inte har att göra med att insatsen i sig innehåller övergrepp. I alla dessa exempel har Socialstyrelsen, genom sin kontrollapparat, en utomordentligt betydelsefull roll som kontrollant och normgivare. Det förefaller vara betydligt viktigare uppgifter än att skjuta in sig på rebirthing och andra udda eller i Sverige inte förekommande interventioner.

3. Till frågan om vår konfrontativa debattstil. Sundell menar att vi genom att ifrågasätta "professorskollegorna från USA" tillskriver dem "låg kompetens". Vi menar i stället att en grundläggande förutsätt- ning för det vetenskapliga samtalet är just ifrågasättanden av vetenskapliga positioner. Att hävda att ifrågasättanden är negativt och konfrontativt är helt enkelt att ersätta ett evidensbaserat förhållningssätt med ett auktoritetsbaserat, där man förväntas tro på kungsorden hos "professorskollegorna från USA" eller Socialstyrelsen utan att skärskåda det vetenskapliga underlaget. Vi tror inte, som Sundell påstår, att Socialstyrelsens uppdrag till rapportförfattarna gjorts i försåtligt syfte, men däremot är vi ytterst förvånande över att man i förordet till Socialstyrelsens rapport och i Sundells inlägg skriver att författarna getts i uppdrag av Socialstyrelsen att reda ut frågan om Drontens dom. Det är inte rapportförfattarnas egen uppfattning, de menar att de inte haft något uppdrag från Socialstyrelsen (se inlägg i detta $\mathrm{nr}$ av Socialvetenskaplig tidskift från Mullen, Shuluk och Soydan).

Än mer förvånade blir vi när vi läser den artikel som Socialstyrelsen rapport bygger på nämligen Mullen och Shuluks (2011) Outcomes of social work intervention in the context of evidence-based practice. Förvånade blir vi eftersom vi instämmer med det mesta som står i den artikeln, men inte med Socialstyrelsens rapport. Artikeln är öppen och diskuterande och pekar på att stödet för förekomsten av specifika effekter på det sociala arbetets fält hittills är ganska svagt och att det framförallt behövs mer forskning. De viktigaste åsiktsskillnaderna mellan oss och Mullen och Shuluk är att de har större tro på att man så småningom skall kunna visa på skillnader i effekt mellan olika former av interventioner. Till skillnad från dem ifrågasätter vi också 
Reids et al. (2004 genomgång av specifika effekter på det sociala arbetets område (se vår ursprungliga artikel och vårt svar till Mullen, Shuluk och Soydan i detta nr av Socialvetenskaplig tidskrift). Socialstyrelsens rapport är långt mer tvärsäker och konfrontativ i sina slutsatser och sammanfattningar än vad som är fallet i Mullen och Shuluks artikel. Varför det blivit så vet vi inte, men de specialintresserade läsarna uppmanas att lägga artikeln och rapporten bredvid varandra och jämföra.

Sundell fastslår, till skillnad från Mullen och Shuluk, att kunskapsläget är avgjort: Socialstyrelsen meddelar med andra ord att det är klarlagt att Drontens dom saknar giltighet, men att om kunskapsläget förändras och visar att "alla insatser är lika effektiva så kommer Socialstyrelsen skyndsamt att informera socialarbetarna och andra professioner om det". Vi skulle bara lite still- samt vilja påpeka att Socialstyrelsen ännu inte kunnat visa att någon specifik insats är bättre än någon annan (se Socialstyrelsen metodguide). Inte heller en genomgång av till exempel Campbell Collaborations omkring sjuttio metaanalyser visar på skillnader i effekt mellan väletablerad interventioner på det sociala arbetets område. Tvärtom två av de senaste (om effekter av KBT vid institutionsvård och om Motivational Interviewing) ger ytterligare stöd för Drontens dom.

Skulle vi inte kunna enas om detta enkla: Så länge det inte är belagt att vissa väletablerade interventioner är bättre än andra på det sociala arbetets område så gäller väl Drontens dom? Till dess kanske vi kan glädja oss åt, men inte slå oss till ro med Mullen och Shuluks påpekande, att det mesta som görs i socialt arbete antagligen har goda effekter jämfört med att inte göra något alls.

\section{Referenser}

Hallerfors, H. (2008) Beteendeträning och nedläggningar, INTRA, 2: 26-29.

Mullen, E. \& Shuluk, J. (2011) Outcomes of social work intervention in the context of evidencebased practice. Journal of Social Work. 11, 49-63.

SBU (2010) Program för att förebygga psykisk ohälsa hos barn: en systematisk forskningsöversikt. Stockholm: SBU.
Söder, M. \& Finn, B. (2009) Hur går det egentligen till när metoder sprids och förändras? Exemplet beteendepåverkande metoder i LSS-verksamhet. FoU-rapport 2009/8, Regionförbundet, Uppsala län.

Reid, WJ, Kenaley, BD \& Colvin, J. (2004) Do some interventions work better than others? A review of comparative social work experiments, Social Work Research, 28, 71-81 